DOI.

https://doi.org/10.22219/fths.v3i1

Received: Desember 2019

Accepted: Januari 2020

Available online: Februari 2020

\title{
Kajian Penambahan Filtrat Kunyit dan Tartrazin Pada Edible Film Berbasis Pati Talas Serta Aplikasinya Untuk Mempertahankan Mutu Dodol Substitusi Rumput Laut (Eucheuma cottonii)
}

\author{
Noor Harini ${ }^{1}$, Mochammad Wachid ${ }^{1 *}$, Tyas Anugrah Hirgawati ${ }^{1}$ \\ ${ }^{1}$ Department of Food Technology; Faculty of Agriculture Animal Science; University of \\ Muhammadiyah Malang \\ *Corresponding author email: mochammadwachid3@umm.ac.id
}

\begin{abstract}
This research studied the effect of natural colorant (turmeric filtrate) additions compared to synthetic colorant (Tartrazin) additions in taro starch based edible film on the quality of dodol that substituted with seaweed. This research used Randomized Block Design with Orthogonal Contrast. The treatment factor consist of turmeric filtrate additions in $1 \%, 2 \%, 3 \%$, Tartrazin additions in 0,003\%, 0,005\%, 0,007\% and without colorant as control treatment. Parameters that analyzed consist of thickness, color, transparency, tensile strength, elongation, water vapor transmission rate of edible film, moisture content, fat content, total plate count, texture and organoleptic value of dodol at the $0,3^{r d}, 6^{\text {th }}$ day of storage. The research result shows that the additions of turmeric filtrate had an effect on increasing thickness, tensile strength, transparency, brightness $(L)$, yellowness $(b+)$ and decreasing the elongation and WVTR of edible film. Meanwhile the additions of Tartrazin had an effect on increasing transparency, brightness $(L)$ and yellowness (b+). The results of moisture content, fat content, TPC and texture of dodol showed that the addition of turmeric filtrate is better to maintain the quality of dodol during storage. Additions of 3\% turmeric filtrate as the best treatment, has $30.24 \%$ and $31.40 \%$ in moisture content, $1.16 \%$ and $0.97 \%$ in fat content, $4.0 \times 10^{3} \mathrm{CFU} / \mathrm{g}$ and $0.9 \times 10^{4}$ CFU/g in TPC, $15.30 \mathrm{~N} / \mathrm{mm}$ and $14.03 \mathrm{~N} / \mathrm{mm}$ in texture, 3.53 and 3.63 in color organoleptic value, 3.65 and 3.60 in aroma value and 3.75 and 3.73 in taste value during the $3^{\text {rd }}$ and $6^{\text {th }}$ day of storage.
\end{abstract}

Keyword: dodol, edible film, food colorant, turmeric, Tartrazin

\section{PENDAHULUAN}

Dodol substitusi rumput laut (Eucheuma cottonii) adalah produk pangan yang banyak beredar di masyarakat. Masa simpan dodol sebagai makanan semi basah hanya sekitar 4-5 hari, karena kadar air yang dimiliki dodol (10-40\%) dan adanya kandungan lemak menyebabkan dodol mudah mengalami ketengikan dan ditumbuhi oleh bakteri serta kapang. Edible film dapat menjadi solusi sebagai kemasan dodol untuk menghambat penurunan mutu tersebut. Fungsi edible film adalah sebagai penghalang transfer kelembaban, oksigen dan zat terlarut serta melindungi produk dari kerusakan mekanis. Edible film dapat 
dibuat dari golongan hidrokoloid yaitu pati talas dan gliserol untuk memperbaiki sifat rapuh film. Hasil penelitian Pangesti dkk. (2014) menunjukkan bahwa edible film dengan warna merah dan hijau lebih disukai panelis dibandingkan edible film pati talas yang bening, sehingga dilakukan penambahan pewarna kuning pada edible film dengan tujuan edible film yang dihasilkan tidak hanya menarik, namun memiliki karakteristik yang baik untuk mendukung fungsinya sebagai pengemas produk dodol substitusi rumput laut.

Kunyit (Curcuma longa L.) merupakan sumber pewarna alami kuning yang ditambahkan berupa filtrat ke dalam edible film, karena adanya kandungan senyawa kurkumin Kurkumin juga seringkali ditambahkan dalam edible film sebagai antibakteri untuk mencegah kontaminasi oleh mikroorganisme yang dapat menurunkan mutu produk (Tarwiyah, 2001). Pewarna kuning sintetis sebagai pembanding adalah Tartrazin yang merupakan pewarna yang umum digunakan, menghasilkan warna pekat dan stabil meski dalam jumlah yang sedikit. Kelebihan dan kelemahan masing-masing pewarna serta penelitian penambahannya untuk meningkatkan kemampuan edible film sebagai pengemas yang baik dan menarik belum banyak dilakukan, menjadi dasar dilakukannya pengkajian penambahan pewarna filtrat kunyit dibandingkan Tartrazin pada edible film untuk mempertahankan mutu dodol substitusi rumput laut selama penyimpanan.

\section{METODE PENELITIAN}

Bahan

Bahan-bahan yang digunakan dalam penelitian ini adalah rumput laut (Eucheuma cottonii) kering dari Madura, ubi talas, rimpang kunyit, yang dibeli dari pasar Mergan Malang, dan pewarna Tartrazin yang dibeli dari toko bahan kimia di Malang.

Alat

Alat-alat yang digunakan dalam penelitian adalah pengering cabinet, laminary air flow, oven (WTC Binder 7200 tipe E53 no. 89749), texture analyzer (Shimadzhu tipe EZ-SX), inkubator, autoklaf, waterbath, kompor, vortex, colony counter, hotplate (Barnstead Thermolyne Cimarec 2), magnetic stirrer, neraca analitik (Pioneer Ohaus tipe PA413), color reader (Konica Minolta tipe CR-10).

\section{Ekstraksi Pati Talas}

Ekstraksi pati talas dilakukan berdasarkan penelitian Ridal (2013). Langkah pertama adalah melakukan pengupasan dan pemotongan talas. Kemudian dilakukan pencucian hingga bersih lalu direndam dalam larutan garam $7,5 \%$ dengan perbandingan $4: 1$ (larutan garam dalam air : talas) selama satu jam yang bertujuan untuk menghilangkan senyawa oksalat. Selanjutnya talas di parut dan di ekstrak patinya dengan perbandingan 1:1 (air : talas). 
Bahan kemudian diperas menggunkan kain saring dan ampasnya ditambah air dengan perbandingan 1:1 (air : ampas) untuk kemudian di ekstraksi kembali. Ekstrak pati diendapkan selama 18 jam, kemudian pati yang telah terbentuk dikeringkan menggunakan pengering kabinet pada suhu kurang lebih $50 \circ \mathrm{C}$ selama 8 jam (sampai kering), lalu dihaluskan dan diayak dengan ayakan 100 mesh.

\section{Pembuatan Filtrat Kunyit}

Pembuatan filtrat kunyit di lakukan berdasarkan modifikasi penelitain Sihombing (2007) dengan langkah pertama membersihkan rimpang kunyit. Kunyit kemudian di kupas dan di iris dengan ketebalan kurang lebih 1-2 mm dan dihaluskan menggunakan blender. Kunyit yang telah halus di peras dan sari kunyit di saring dengan kertas Whatman no. 42 sehingga di dapatkan filtrat kunyit.

\section{Pembuatan Edible Film}

Edible film dibuat dari modifikasi penelitian Pangesti, dkk. (2014). Proses pertama adalah melarutkan 4 gram pati talas dalam aquades dengan volume total $150 \mathrm{ml}$ pada tiap perlakuan ke dalam gelas beker, kemudian ditambah $1 \mathrm{ml}$ gliserol. Selanjutnya dilakukan pemanasan di atas hotplate stirrer hingga suhu mencapai $85 \circ \mathrm{C}$ dan dipertahankan selama 5 menit. Proses selanjutnya adalah menambahkan pewarna sesuai perlakuan yaitu tartrazine dengan konsentrasi $0,003,0,005,0,007 \%$ atau filtrat kunyit dengan konsentrasi $1,2,3 \%$ dengan pengadukan selama 5 menit. Larutan edible kemudian dituang dalam plat kaca plastik dan dilakuan pengeringan menggunakan pengering kabinet pada suhu 50 o C selama 18-24 jam. Pengeringan dihentikan saat film mudah lepas dari plat. Setelah kering, edible film didinginkan pada suhu ruang selama 15 menit dan kemudian dilepas dari plat plastik. Selanjutnya edible film dianalisis karakteristik fisik dan mekaniknya dan diaplikasikan pada dodol substitusi rumput laut.

\section{Pembuatan Dodol Rumput Laut dan Pengaplikasian Edible Film}

Proses pembuatan dodol rumput laut diawali dengan pembuatan bubur rumput laut. Proses pembuatannya meliputi perendaman rumput laut selama 24 jam, dilanjutkan dengan proses penghalusan menggunakan blender. Pembuatan dodol dilaksanakan berdasarkan penelitian Astawan, dkk. (2004) yang meliputi empat tahap, yaitu: pemasakan santan kelapa, kemudian pemasakan dan pengadukan pertama, kedua dan ketiga. Tahap pertama adalah pemasakan santan kental pada suhu $\pm 720 \mathrm{C}$ selama 20 menit, kemudian diambil sebanyak $200 \mathrm{ml}$ krim santan. Pengadukan pertama dilakukan pada proses pencampuran antara 100 gram tepung ketan dengan $200 \mathrm{ml}$ air. Pengadukan pertama selesai jika penampakan adonan telah halus, mengkilap, mengental dan bila diteteskan tampak terputus. 
Pada tahap pengadukan kedua dilakukan penambahan 150 gram gula pasir dan 100 gram gula merah. Pengadukan dianggap telah mencapai tingkat kematangan yang cukup jika teksturnya sudah kenyal dan tidak lengket di penggorengan. Tahap pengadukan ketiga ditambahkan bubur rumput laut 250 gram. Adonan dinyatakan telah matang bila diteteskan mulur dan tidak terputus. Setelah tahap pemasakan terakhir selama satu jam, adonan dipindahkan ke dalam loyang. Dodol yang telah dingin dipotong $(3 \times 3 \mathrm{~cm})$ dan edible film dilapiskan hingga seluruh permukaan dodol terlapisi, kemudian di analisis mutu nya pada penyimpanan hari ke-0, 3 dan 6 .

\section{Parameter Penelitian}

Edible film pati talas yang dihasilkan dari ke tujuh perlakuan masingmasing diuji karakteristik fisik (ketebalan, laju transmisi uap air, warna dan transparansi) serta karakteristik mekaniknya (kekuatan tarik dan elongasi). Selanjutnya edible film masing-masing perlakuan di aplikasikan pada dodol substitusi rumput laut, kemudian diuji kadar air, kadar lemak, tekstur, angka lempeng total (total plate count/TPC) dan nilai organoleptiknya (rasa, aroma, warna) selama periode penyimpanan 0,3 , dan 6 hari.

\section{Rancangan Percobaan dan Analisa Data}

Rancangan percobaan yang digunakan adalah Rancangan Acak Kelompok (RAK) Kontras Orthogonal dengan satu faktor dan 4 kali ulangan. Faktor perlakuan adalah penambahan pewarna filtrat kunyit $(1 \%, 2 \%, 3 \% \mathrm{v} / \mathrm{v})$, pewarna Tartrazin $(0,003 \%, 0,005 \%, 0,007 \% \mathrm{~b} / \mathrm{v})$, dan 1 perlakuan kontrol (edible film tanpa penambahan pewarna).

Data hasil penelitian diuji secara statistika menggunakan analisis ragam atau ANOVA (Analysis of Variance) dengan metode Rancangan Acak Kelompok (RAK) Kontras Orthogonal. Jika hasil menunjukkan adanya perbedaan antar perlakuan, kemudian dilakukan uji lanjut metode DMRT (Duncan Multiple Range Test) untuk mengetahui notasi yang berbeda pada perlakuan terhadap parameter yang diuji. Selanjutnya dilakukan penentuan perlakuan terbaik dengan menggunakan metode uji efektifitas membandingkan langsung dengan SNI dodol beras ketan (SNI No. 01-2986-2013).

\section{HASIL DAN PEMBAHASAN \\ Karakteristik Edible Film}

Hasil pengujian terhadap karakteristik yang meliputi ketebalan, transparansi, kuat tarik, elongasi dan laju transmisi uap air (WVTR) pada edible film berbasis pati talas dengan penambahan pewarna alami filtrat kunyit, pewarna sintetis Tartrazin dan perlakuan kontrol tanpa penambahan pewarna disajikan dalam Tabel 1. 
Tabel 1. Karakteristik Edible Film Pati Talas dengan Penambahan Pewarna

\begin{tabular}{cccccc}
\hline Perlakuan & $\begin{array}{c}\text { Ketebalan } \\
(\mathrm{mm})\end{array}$ & $\begin{array}{c}\text { Transparansi } \\
\left(\mathrm{A}_{546} / \mathrm{mm}\right)\end{array}$ & $\begin{array}{c}\text { Kuat tarik } \\
(\mathrm{MPa})\end{array}$ & $\begin{array}{c}\text { Elongasi } \\
(\%)\end{array}$ & $\begin{array}{c}\text { WVTR } \\
\left(\mathrm{g} / \mathrm{m}^{2} / \mathrm{hari}\right)\end{array}$ \\
\hline K1 & $0,14^{\mathrm{b}}$ & $3,10^{\mathrm{b}}$ & $1,81^{\mathrm{b}}$ & $26,09^{\mathrm{c}}$ & $5,84^{\mathrm{c}}$ \\
K2 & $0,16^{\mathrm{c}}$ & $3,41^{\mathrm{c}}$ & $2,12^{\mathrm{c}}$ & $25,15^{\mathrm{b}}$ & $5,37^{\mathrm{b}}$ \\
K3 & $0,18^{\mathrm{d}}$ & $3,75^{\mathrm{d}}$ & $2,42^{\mathrm{d}}$ & $24,31^{\mathrm{a}}$ & $4,86^{\mathrm{a}}$ \\
T1 & $0,11^{\mathrm{a}}$ & $4,57^{\mathrm{e}}$ & $1,51^{\mathrm{a}}$ & $27,63^{\mathrm{d}}$ & $6,47^{\mathrm{d}}$ \\
T2 & $0,12^{\mathrm{a}}$ & $4,92^{\mathrm{f}}$ & $1,51^{\mathrm{a}}$ & $27,11^{\mathrm{d}}$ & $6,40^{\mathrm{d}}$ \\
T3 & $0,12^{\mathrm{a}}$ & $5,36^{\mathrm{g}}$ & $1,52^{\mathrm{a}}$ & $27,01^{\mathrm{d}}$ & $6,35^{\mathrm{d}}$ \\
A0 & $0,11^{\mathrm{a}}$ & $0,93^{\mathrm{a}}$ & $1,51^{\mathrm{a}}$ & $27,65^{\mathrm{d}}$ & $6,62^{\mathrm{d}}$ \\
\hline
\end{tabular}

Angka yang diikuti huruf yang sama menunjukkan tidak berbeda nyata pada uji Duncan $\alpha=5 \%$ K1: filtrat kunyit $1 \%$, K2: filtrat kunyit $2 \%$, K3: filtrat kunyit $3 \%$

T1: Tartrazin 0,007\%, T2: Tartrazin 0,005\%, T3: Tartrazin 0,007\%, A0: kontrol

Hasil analisis ragam menunjukkan perbedaan nyata pada perlakuan penambahan pewarna terhadap ketebalan edible film. Berdasarkan Japanese Industrial Standards (1997), ketebalan edible film maksimal 0,25 mm, sehingga ketebalan edible film pada penelitian ini memenuhi standar. Ketebalan meningkat seiring peningkatan konsentrasi filtrat kunyit, sedangkan perlakuan penambahan Tartrazin dan kontrol tidak berbeda nyata (Tabel 1). Hal tersebut diduga disebabkan penambahan filtrat kunyit mampu meningkatkan total padatan sehingga semakin banyak polimer yang menyusun matriks edible film akan meningkatkan ketebalan. Friedman (2009) menyatakan bahwa penambahan filtrat kunyit meningkatkan jumlah total padatan sehingga ketebalan edible film meningkat.

Hasil analisis ragam menunjukkan perbedaan nyata pada perlakuan penambahan pewarna terhadap transparansi edible film. Transparansi tertinggi dimiliki oleh penambahan tartazine $0,007 \%$ dan terendah pada perlakuan kontrol (Tabel 1). Transparansi meningkat seiring peningkatan konsentrasi Tartrazin dan filtrat kunyit yang disebabkan semakin banyak partikel zat warna yang terdispersi dalam matriks edible film. Kampeerapappun dkk. (2007) bahwa partikel terdispersi dalam matriks edible film yang lebih besar dari panjang gelombang visible akan menghalangi cahaya sehingga diketahui film tersebut transparan atau buram.

Hasil analisis ragam menunjukkan perbedaan nyata pada perlakuan penambahan pewarna terhadap nilai kuat tarik edible film. Berdasarkan Japanese Industrial Standards (1997), kuat tarik edible film minimal 0,39 MPa, sehingga edible film pada penelitian ini memenuhi standar. Perlakuan filtrat kunyit 3\% memiliki kuat tarik tertinggi dan kontrol memiliki kuat tarik tidak berbeda nyata dengan penambahan Tartrazin (Tabel 1). Kuat tarik meningkat seiring peningkatan konsentrasi filtrat kunyit yang diduga akibat peningkatan total padatan termasuk pati (polisakarida) yang saling berikatan dan membentuk struktur film menjadi lebih tebal dan kompak sehingga mampu 
menahan kerusakan dari gaya luar yang diberikan. Nasaputra (2012) menyatakan bahwa pemanasan polisakarida dan air menyebabkan terjadinya pengikatan dan pelepasan air membentuk jaringan tiga dimensi yang menghasilkan gel yang kuat. Sehingga kuat tarik meningkat. Hasil analisis ragam menunjukkan perbedaan nyata pada perlakuan penambahan pewarna terhadap nilai elongasi edible film. Nilai elongasi berbanding terbalik dengan kuat tarik edible film. Perlakuan Penambahan filtrat kunyit 3\% memiliki elongasi terendah (Tabel 1). Hal tersebut diduga disebabkan peningkatan konsentrasi filtrat kunyit yang menyebabkan kuat tarik meningkat sehingga kemampuan perenggangan edible film menurun. Kusumawati dan Putri (2013) menyatakan bahwa padatan terlarut dalam perasan temu hitam yang ditambahkan dalam edible film diduga memperkokoh matriks film dan menurunkan elongasi. Penambahan Tartrazin dan kontrol memiliki elongasi tinggi yang disebabkan kuat tarik yang rendah sehingga edible film lebih fleksibel. Ikatan antar molekul yang rapat dan kompak menyebabkan edible film menjadi kuat, sehingga semakin sulit untuk merenggang dan prosentase pemanjangan edible film semakin rendah.

Hasil analisis ragam menunjukkan bahwa WVTR edible film berbeda nyata (Tabel 1). Berdasarkan Japanese Industrial Standards (1997) WVTR maksimal $7 \mathrm{~g} / \mathrm{m}^{2} /$ hari, sehingga edible film pada penelitian ini memenuhi standar. Perlakuan kontrol memiliki rerata WVTR tertinggi, sedangkan filtrat kunyit 3\% memiliki WVTR terendah (Tabel 1). Semakin tinggi konsentrasi filtrat kunyit maka nilai WVTR menurun yang diduga akibat peningkatan ketebalan sehingga struktur edible film semakin rapat dan sulit dilewati uap air. Santoso dkk. (2016) menyatakan bahwa penambahan bahan yang dapat mengisi matrik edible film menyebabkan edible film semakin padat sehingga nilai laju transmisi uap airnya semakin rendah.

\section{Analisis Warna Edible Film}

Hasil pengujian terhadap kecerahan (L) dan kekuningan $(\mathrm{b}+)$ edible film berbasis pati talas dengan penambahan pewarna disajikan dalam Tabel 2. Tabel 2. Nilai Rerata Kecerahan (L) dan Kekuningan (b+) Edible Film

\begin{tabular}{lcc}
\hline Perlakuan & Kecerahan (L) & Kekuningan $(\mathrm{b}+)$ \\
\hline K1 (filtrat kunyit 1\%) & $36,9^{\mathrm{f}}$ & $6,3^{\mathrm{b}}$ \\
K2 (filtrat kunyit 2\%) & $35,9^{\mathrm{e}}$ & $7,1^{\mathrm{c}}$ \\
K3 (filtrat kunyit 3\%) & $34,9^{\mathrm{d}}$ & $7,6^{\mathrm{d}}$ \\
T1 (Tartrazin 0,003\%) & $33,3^{\mathrm{c}}$ & $8,5^{\mathrm{e}}$ \\
T2 (Tartrazin 0,005\%) & $32,4^{\mathrm{b}}$ & $9,3^{\mathrm{f}}$ \\
T3 (Tartrazin 0,007\%) & $30,2^{\mathrm{a}}$ & $10,5^{\mathrm{g}}$ \\
Kontrol (tanpa & $40,2^{\mathrm{g}}$ & $2,3^{\mathrm{a}}$ \\
pewarna) & &
\end{tabular}


Hasil analisis ragam menunjukkan perbedaan nyata pada perlakuan penambahan pewarna terhadap nilai kecerahan film. Kecerahan edible film berpewarna saling berbeda nyata dan lebih rendah dibandingkan kontrol (Tabel 2). Peningkatan konsentrasi filtrat kunyit menyebabkan penurunan kecerahan yang diduga dipengaruhi oleh ketebalannya dan kurkumin yang meningkatkan warna kuning edible film. Menurut Syarifuddin dan Yunianta (2015), edible film menurun kecerahannya akibat peningkatan jumlah polimer penyusun matriks, sehingga ketebalan meningkat dan mempengaruhi pembaur cahaya sehingga edible film nampak buram. Peningkatan konsentrasi Tartrazin akan menurunkan kecerahan edible film akibat warna kuning yang diberikan oleh Tartrazin menyebabkan edible film semakin menjauhi warna putih. Miller (1982) dalam Winarno (2004) menyatakan bahwa Tartrazin memberikan warna kuning yang stabil dan pekat.

Hasil analisis ragam menunjukkan adanya perbedaan nyata pada perlakuan penambahan pewarna terhadap nilai kekuningan edible film. Penambahan Tartrazin memiliki tingkat kekuningan yang lebih tinggi dibandingkan perlakuan penambahan filtrat kunyit. Hal tersebut diduga disebabkan kemampuan Tartrazin untuk memberikan warna kuning yang pekat dan homogen sehingga nilai $\mathrm{b}+$ yang terukur oleh color reader semakin tinggi. Berdasarkan Rahmayani (2011), keunggulan Tartrazin adalah warnanya yang pekat dan stabil. Peningkatan kekuningan akibat penambahan filtrat kunyit disebabkan peningkatan kadar kurkumin seiring peningkatan konsentrasi filtrat kunyit dalam film. Rahayu (2016) melaporkan bahwa semakin banyak penambahan filtrat kunyit pada edible film berbasis ubi kimpul, ubi jalar dan singkong menyebabkan warna kuning pada edible film semakin meningkat.

\section{Analisis Mutu Dodol Substitusi Rumput Laut Kadar Air}

Hasil penelitian menunjukkan bahwa kadar air dodol semakin meningkat selama penyimpanan (Gambar 1). Hal ini diduga karena uap air hasil penguapan dodol terakumulasi karena tertahan edible film serta air bebas meningkat akibat penurunan kemampuan pati mengikat air. Menurut Herawati (2008), kadar air akan meningkat selama penyimpanan. Pati dalam tepung ketan akan menurun kemampuannya untuk mengikat air sehingga air bebas dalam produk meningkat. 

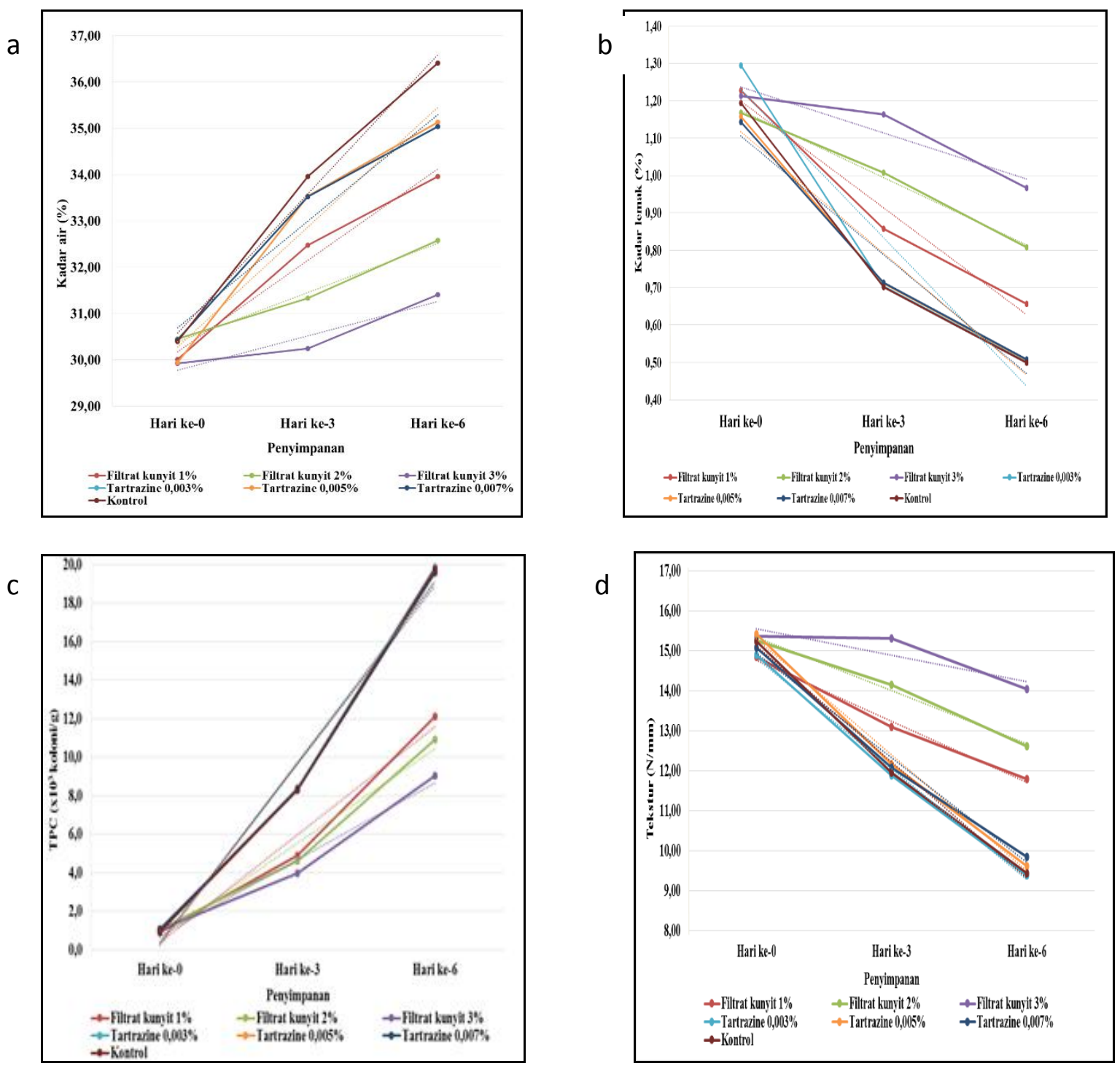

\section{Gambar 1. Grafik Kadar Air (a), Lemak (b), TPC (c), dan Tekstur (d) Dodol Selama Penyimpanan}

Berdasarkan Gambar 1, perlakuan filtrat kunyit 3\% memiliki kadar air terendah pada hari ke-3 dan ke-6. Hal tersebut diduga disebabkan edible film dengan penambahan filtrat kunyit lebih tebal dan laju transmisi uap airnya rendah, sehingga dapat menghambat peningkatan kadar air. Praseptiangga (2003) dalam Wulandari (2017) menyatakan bahwa semakin tebal film, maka jarak tempuh uap air untuk kontak dengan produk yang dikemasnya semakin jauh dan butuh waktu lama. Sedangkan kontrol memiliki kadar air tertinggi pada hari ke-3 dan ke-6 yang tidak berbeda nyata dengan penambahan Tartrazin, akibat dari ketebalan film yang rendah sehingga laju transmisi uap airnya lebih besar. Sudarmadji (1989) dalam Ayu (2016) menyatakan bahan 
pangan bersifat higroskopis, yaitu dapat menyerap air dari udara sekelilingnya dan juga sebaliknya sehingga tercapai kadar air kesetimbangan dengan kelembaban relatif udara di sekitarnya.

\section{Kadar Lemak}

Hasil penelitian menunjukkan bahwa kadar lemak dodol menurun selama penyimpanan (Gambar 1b). Hal ini diduga karena terjadi reaksi oksidasi dan hidrolisis lemak. Atmaka dkk. (2012) menyatakan bahwa lemak dalam dodol mudah mengalami oksidasi serta keberadaan air akan bereaksi dengan lemak. Berdasarkan Gambar 1b, perlakuan filtrat kunyit 3\% memiliki kadar lemak tertinggi pada penyimpanan hari ke-3 dan ke-6. Sedangkan kadar lemak perlakuan kontrol dan perlakuan penambahan Tartrazin lebih rendah. Hal tersebut diduga disebabkan penambahan filtrat kunyit menyebabkan edible film lebih tebal dan adanya kurkumin sebagai zat aktif dapat berperan sebagai antibakteri sehingga aktifitas perombakan lemak oleh mikroorganisme terhambat. Ayu dkk. (2016) menyatakan bahwa penguraian bahan pangan oleh mikroorganisme dimulai dari penguraian karbohidrat, protein dan kemudian lemak. Yuliati (2016) melaporkan bahwa kurkumin berperan sebagai antibakteri yang dapat mendenaturasi protein penyusun dinding sel bakteri sehingga bakteri mengalami lisis serta berfungsi sebagai antioksidan untuk melindungi lemak dari kerusakan akibat proses oksidasi.

\section{Total Plate Count (TPC)}

Berdasarkan SNI No. 01-2986-2013, TPC dodol maksimal 1x104 koloni/g, sehingga dodol dalam penelitian ini memenuhi standar. Nilai TPC dodol meningkat selama penyimpanan (Gambar 1c). Menurut Jay (2005), adanya kandungan air, protein dan lemak adalah sumber energi yang dapat meningkatkan jumlah mikroba.

Berdasarkan Gambar 1c, perlakuan filtrat kunyit 3\% memiliki nilai TPC terendah pada penyimpanan hari ke-3 dan ke-6. Sedangkan perlakuan kontrol memiliki nilai TPC tertinggi pada hari ke-3 dan ke-6 dan berbeda nyata dengan perlakuan penambahan Tartrazin. Hal tersebut diduga akibat penambahan filtrat kunyit meningkatkan kadar kurkumin dalam edible film yang memiliki fungsi sebagai antibakteri dan antifungi, sehingga pertumbuhan dan kontaminasi mikroba terhambat. Berdasarkan Egan dkk. (2004), kurkumin berpengaruh sebagai antibakteri terhadap Escherichia coli dan Staphylococcus aureus. Kurkumin juga mempunyai aktifitas perusakan pada Aspergilus Niger, Penicillium notatum dan Saccharomyces cereviseae. Suhajati (1995) dalam Ningrum (2010) menyatakan bahwa kapang terbanyak yang berhasil diisolasi dan diidentifikasi dalam produk dodol Garut selama penyimpanan adalah dari jenis Aspergilus dan Penicillium. Tekstur 
Hasil penelitian menunjukkan bahwa tekstur dodol menurun selama penyimpanan (Gambar 1d). Hal ini diduga disebabkan dodol mengalami peningkatan kadar air sehingga dodol semakin lunak. Menurut Wulandari (2017), perubahan tekstur disebabkan retrogradasi, reaksi enzimatik dan penyerapan air. Edible film yang menurun kemampuannya seiring lama penyimpanan akan mudah dilewati uap air dan menurunkan tekstur dodol.

Perlakuan filtrat kunyit 3\% memiliki nilai tekstur tertinggi pada hari ke-3 dan ke-6 (Gambar 1d). Sedangkan perlakuan penambahan Tartrazin dan perlakuan kontrol memiliki nilai tekstur yang lebih rendah. Hal tersebut diduga dipengaruhi oleh kadar air perlakuan kontrol dan penambahan Tartrazin memiliki yang lebih tinggi dibanding perlakuan penambahan kunyit sehingga tekstur dodol semakin lunak. Selain itu edible film perlakuan penambahan filtrat kunyit memiliki laju transmisi uap air yang lebih rendah sehingga peningkatan kadar air dan penurunan nilai tekstur dapat dihambat. Ayu dkk., (2016) menyatakan bahwa tekstur pada dodol mengalami penurunan seiring dengan peningkatan kadar airnya. Kandungan air dapat mempengaruhi kenampakan, tekstur serta citarasa makanan.

\section{Organoleptik}

Warna, Aroma dan Rasa

Nilai rerata uji organoleptik warna, aroma dan rasa dodol substitusi rumput laut yang dilapisi dengan edible film dengan penambahan pewarna, selama penyimpanan hari ke-0, 3 dan 6 tertera pada Gambar 2. Nilai organoleptik warna dodol yang dilapisi edible film menurun selama penyimpanan (Gambar 5). Nilai warna edible film yang tertinggi selama penyimpanan adalah perlakuan filtrat kunyit $3 \%$ dan terendah pada kontrol. Hasil tersebut diduga disebabkan panelis lebih menyukai warna kuning pada perlakuan filtrat kunyit 3\%, bila dibandingkan warna kuning mengkilap hasil dari perlakuan penambahan Tartrazin dan edible film yang transparan. Sesuai dengan penelitian Pangesti dkk. (2014), edible film yang berwarna merah dan berwarna hijau lebih disukai panelis dibandingkan edible film berbasis pati talas yang bening.

Nilai organoleptik aroma dodol menurun selama penyimpanan kecuali perlakuan kontrol dan filtrat kunyit 3\% yang fluktuatif (Gambar 6). Nilai yang dimiliki perlakuan selama penyimpanan hari ke-0, 3, dan 6 berkisar antara,103,65 yang berarti dodol memiliki nilai cukup sedap yang diterima panelis. Faktor yang dapat menyebabkan perbedaan penilaian aroma adalah preferensi panelis terhadap aroma dodol. Estiasih dan Ahmadi (2009) menyatakan bahwa selama penyimpanan dapat terjadi reaksi kimia yang mengakibatkan perubahan bau dan rasa. 
a

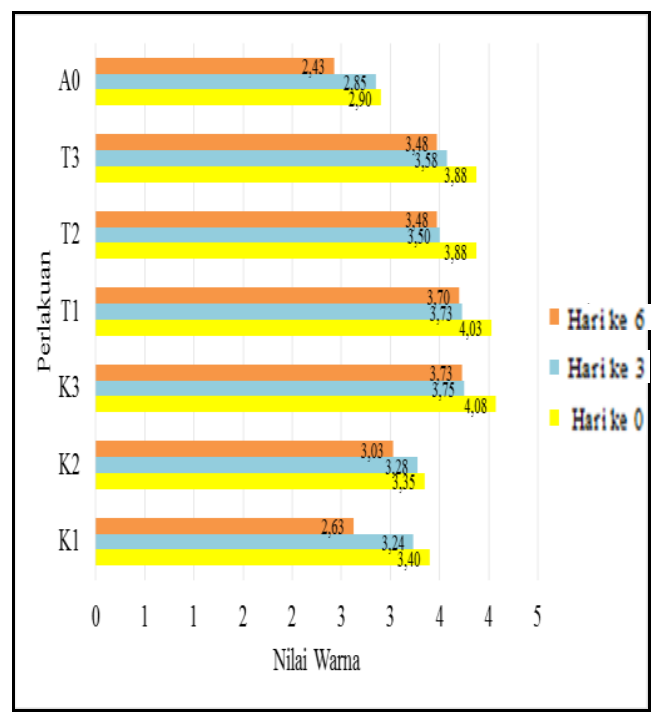

C

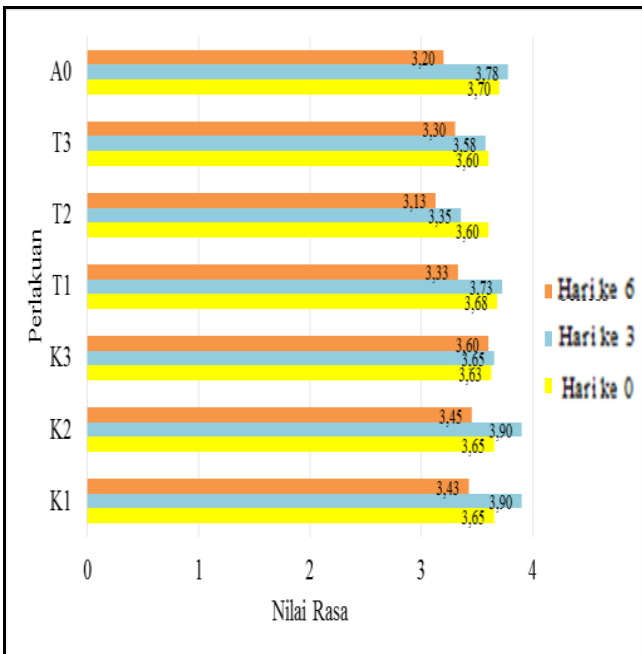

b

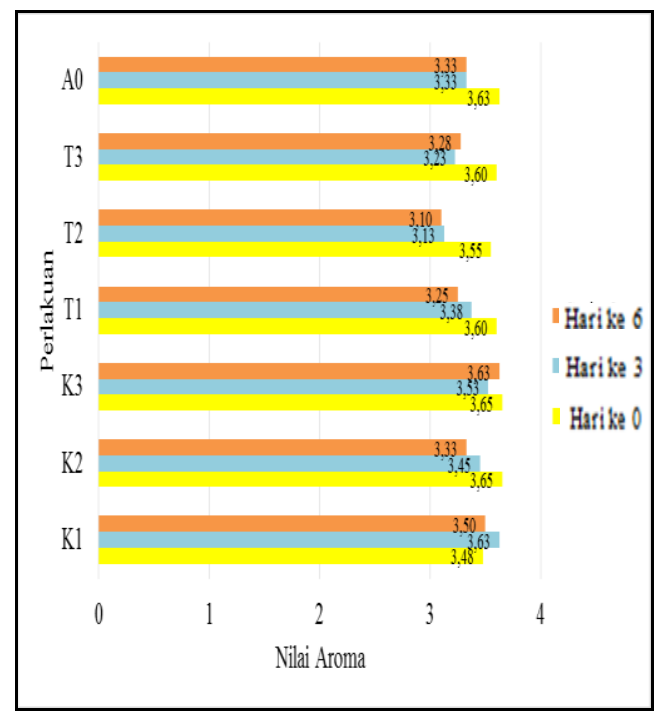

Gambar 2. Rerata Nilai Organoleptik Warna (a), Aroma (b), dan Rasa (c) Dodol dengan Pelapisan Edible Film

Keterangan:

$\mathrm{K} 1, \mathrm{~K} 2, \mathrm{~K} 3=$ Penambahan filtrat kunyit $1 \%, 2 \%, 3 \%$

T1, T2, T3 = Penambahan Tartrazin $0,001 \%, 0,003 \%, 0,005 \%$

A0 $\quad$ Tanpa pewarna

Skor Penilaian: Warna/ Aroma/ Rasa

1 = sangat tidak menarik/ sedap/ enak,

$2=$ tidak menarik/ sedap/ enak

$3=$ cukup menarik/ sedap/ enak

$4=$ menarik/ sedap/ enak

5 = sangat menarik/ sedap/ enak

Nilai organoleptik rasa dodol perlakuan kontrol dan penambahan Tartrazin menurun selama penyimpanan, sedangkan perlakuan penambahan filtrat kunyit (1\%, 2\% dan 3\%) fluktuatif (Gambar 7 ). Nilai rasa yang dimiliki 
perlakuan antara 3,60-3,70 pada hari ke-0, 3,50-3,90 pada hari ke-3 dan 3,133,60 pada hari ke-6 yang menandakan bahwa rasa dodol masih dapat diterima oleh panelis. Beberapa faktor yang dapat menyebabkan perbedaan penilaian terhadap rasa dodol selama penyimpanan diantaranya preferensi panelis terhadap rasa dodol yang diinginkan. Menurut Sachiko (2002), kesukaan makan meningkatkan preferensi pangan. Sehingga dapat disimpulkan bahwa kesukaan seseorang akan rasa ditentukan oleh hati.

\section{Penentuan Perlakuan Terbaik}

Penentuan perlakuan terbaik dilakukan dengan membandingkan parameter dodol yang diuji pada hari ke-3 dan ke-6 dengan SNI dodol. Penambahan filtrat kunyit $3 \%$ dalam edible film sebagai perlakuan terbaik memiliki kadar air dodol pada hari ke-3 sebesar 30,24\% dan meningkat menjadi $31,40 \%$ pada hari ke-6. Kadar lemak hari ke-3 sebesar $1,16 \%$ dan menurun menjadi $0,97 \%$ pada hari ke-6. TPC sebesar $4,0 \times 10^{3}$ koloni/g meningkat menjadi $0,9 \times 10^{4} \mathrm{koloni} / \mathrm{g}$; tekstur sebesar $15,30 \mathrm{~N}$ menurun menjadi $14,03 \mathrm{~N}$; nilai warna sebesar 3,75 menurun menjadi 3,73; aroma sebesar 3,53 meningkat menjadi 3,63; dan rasa 3,65 menurun menjadi 3,60.

\section{KESIMPULAN}

Penambahan filtrat kunyit berpengaruh pada ketebalan, kuat tarik, transparansi, kecerahan, kekuningan, elongasi dan laju transmisi uap air edible film. Penambahan Tartrazin berpengaruh pada transparansi, kecerahan dan kekuningan edible film. Penambahan filtrat kunyit $3 \%$ sebagai perlakuan terbaik, secara berurutan pada penyimpanan hari ke-3 dan ke-6, memiliki kadar air sebesar $30,24 \%$ dan 31,40\%, kadar lemak 1,16\% dan 0,97\%, TPC 4,0x103 koloni/g dan 0,9x104 koloni/g, tekstur 15,30 N.mm dan 14,03 N/mm, nilai organoleptik warna 3,53 dan 3,63 , nilai aroma 3,65 dan 3,60 serta nilai rasa 3,75 dan 3,73 .

\section{REFERENSI}

Ayu, S. P., A. D. Sutrisno, Doddy dan D. A. Darmajana. 2016. Pendugaan Umur Simpan Dodol Nanas (Ananas comosus L.) dengan Pengemas Edible Film Tapioka. Institut Pertanian Bogor. Bogor.

Egan, M. E. M. Pearson., S. A. Weiner, Rajendran V., Rubin D., Glöckner-Pagel J., Canny S, Du K, Lukacs G. L. dan Caplan M. J., 2004. Curcumin, a Major Constituent of Turmeric, Corrects Cystic Fibrosis Defects. Science: 600-2.

Estiasih, T. dan Ahmadi. 2009. Teknologi Pengolahan Pangan. Bumi Aksara. Jakarta.

Friedman, M. 2009. Cinnamaldehyde Content in Foods Determined by Gas Chromatography-mass Spectrometry. J Agric Food Chem 48 (11):5702-9. 
Japanese Industrial Standards. 1997. JIS Z 1707: 1997 General Rules of Plastic Films for Food Packaging. JSA. Tokyo.

Jay, J. M. 2005. Modern Food Microbiology Seventh Edition. Springer Science and Business Media. Maryland.

Kampeerapappun dan Piyaporn. 2007. Preparation of Cassava Starch/ Montmorillonite Composite Film. Chulalongkorn University. Bangkok.

Kusumawati, D. H dan W. D. R. Putri. 2013. Karakteristik Fisik dan Kimia Edible Film Pati Jagung yang diinkorporasi dengan Perasan Temu Hitam. Jurnal Pangan dan Agroindustri Vol. 1, No. 1. Halaman: 90-100.

Nasaputra, M. A. 2012. Pengaruh Konsentrasi Pati Jahe Emprit (Zingiber officinale var. Rubrum) dan Asam Stearat terhadap Karakteristik Fisik, Kimia, dan Organoleptik Edible Film. Skripsi. Universitas Brawijaya. Malang.

Pangesti, A. D., A. Rahim dan G. S. Hutomo. 2014. Karakteristik Fisik, Mekanik dan Sensoris Edible Film dari Pati Talas pada berbagai Konsentrasi Asam Palmitat. E-J. Agrotekbis. 2 (6): 604-610.

Sachiko, A. 2002. The Determinant of Food Preference. Journal for the Integrated Study of Dietary Habits. Vol. 13. Halaman 17-21.

Santoso, B., A. Marsega., G. Priyanto dan R. Pambayun. 2016. Perbaikan Sifat Fisik, Kimia dan Antibakteri Edible Film Berbasis Pati Ganyong. Jurnal Agritech, Vol. 36, No. 4. Halaman 379-386.

Standar Nasional Indonesia. 2013. Dodol Beras Ketan. SNI-2986:2013. Badan Standarisasi Nasional. Jakarta.

Syarifuddin, A. dan Yunianta. 2015. Karakterisasi Edible Film dari Pektin Jeruk Bali. Jurnal Pangan dan Agroindustri. Vol 3, No. 4. Halaman 1538-1547.

Tarwiyah. 2001. Minyak Atsiri Jahe. Online. Diakses pada 5 November 2018. http://www.ristek.go.id.

Winarno, F. G. 2004. Keamanan Pangan. Jilid 1. Gramedia Pustaka Utama. Jakarta.

Wulandari, Y. 2017. Karakterisasi Edible Film dari Pati Umbi Talas (Colocasia esculenta (L.) Schott) dengan Penambahan Kitosan pada Dodol Substitusi Rumput Laut (Eucheuma cottonii L.). Skripsi. Universitas Muhammadiyah Malang. Malang.

Yuliati. 2016. Uji Efektivitas Ekstrak Kunyit sebagai Antibakteri dalam Pertumbuhan Bacillus sp dan Shigella dysentriae secara In Vitro. Jurnal Profesi Medika Vol. 10, No. 1. Halaman 26-32. 